\title{
Effect of a lactic acid bacterial inoculant on the fermentation characteristics of cereal and alfalfa forages
}

\author{
GR Khorasani, JJ Kennelly \\ Department of agricultural, food and nutritional science, University of Alberta, Edmonton, AB T6G 2P5, Canada
}

Bacterial inoculants are used to enhance silage fermentation (lowering $\mathrm{pH}$, increasing lactic acid to acetic acid ratio, reducing ammonia), especially under poor ensiling conditions (Kung et al, 1993, J Dairy Sci, 76, 3763-3770 ; Wohit, 1989, J Dairy Sci, 72, 545-551). Research on the efficacy of inoculants has primarily focused on forages such as alfalfa, grass and corn. Data on the effect of inoculants on the fermentation characteristics of cereal silages are limited. Therefore, the primary objective of this study was to evaluate the effect of a lactic acid bacterial inoculant on the quality of cereal silages under practical conditions in Alberta, Canada. Alfalfa forage was also treated with the same inoculant for comparison purposes.

The effect of applying a commercial inoculant (AG BAG ${ }^{\circledR}$ Plus) to barley/triticale, triticale/peas and alfalfa silage was studied. The inoculant was applied at $250 \mathrm{~g}$ per tonne of fresh crop. A total of six silage bags (40 t/bag) were filled; three contained treated forage and three control forage. After ensiling, samples were taken from each bag at one week interval for up to six weeks and fermentation characteristics of the silage were measured. To test the effects of added inoculant and ensiling period, standard ANOVA techniques were used with a model that included the silage type, week of sampling and treatment (inoculant vs control). The data were also separated by silage type and analyzed based on week of sampling and treatment.
In general, silage $\mathrm{pH}$ was lowest $(\mathrm{P}<0.05)$ for triticale/peas silage, intermediate for barley/triticale silage and highest for alfalfa silage. Although the inoculant decreased $(\mathrm{P}<0.05)$ the $\mathrm{pH}$ of the silages tested $(4.34 \mathrm{vs}$ 4.46 for treated and untreated, respectively), the extent of change was very moderate. Addition of inoculant to silages did not affect ammonia $\mathrm{N}(20.5 \pm 2.32, \mathrm{~g} / \mathrm{kg}$ of $\mathrm{DM})$, butyric acid $(0.12 \pm 0.1, \mathrm{~g} / \mathrm{kg}$ of $\mathrm{DM})$ and lactic acid $(91.2 \pm 10.4, \mathrm{~g} / \mathrm{kg}$ of DM) content of silages. When the effect of treatment on silage fermentation characteristics was separated based on crop type, the $\mathrm{pH}$ of alfalfa silage was lower but the $\mathrm{pH}$ of barley/triticale and triticale/peas silage were unchanged. Fermentation characteristics of individual silages, based on the $\mathrm{pH}$ (being lower) and lactic acid concentration (being higher), were used to rate silage quality in the order of triticale/peas, barley/triticale and alfalfa silage. The addition of inoculant resulted in a lower $\mathrm{pH}$ and greater lactic acid concentration after 7-d of ensiling for all three silages, but after the first week of ensiling the effects of inoculant on the ensiling process were very minor. Therefore, it is concluded that under the good ensiling conditions of this study, the inoculant had a relatively minor influence on the fermentation characteristics of the silage. In addition, the effect of inoculant on fermentation patterns in silage bags was influenced by forage species. 